\title{
Corrosion Behaviour of SS316L in Artificial Blood Plasma in Presence of Amoxicillin
}

\author{
S. John Mary ${ }^{a, *}$ and S. Rajendran ${ }^{b}$ \\ ${ }^{a}$ Department of Chemistry, Loyola College, Chennai, Tamil Nadu, India \\ ${ }^{b}$ Department of Chemistry, RVS School of Engineering \& Technology, RVS Nagar, \\ Dindigul-624005, Tamil Nadu, India
}

Received 27 November 2012; accepted 12 February 2013

\begin{abstract}
An investigation about the corrosion resistance of SS316L alloys in artificial blood plasma environments in presence and absence of amoxicillin has been carried out by using electrochemical techniques. Tested alloys included $18 \% \mathrm{Cr}, 12 \% \mathrm{Ni}, 2.5 \% \mathrm{Mo}$, $<0.03 \mathrm{C}$, balance iron, using artificial blood plasma solution. Electrochemical techniques included potentiodynamic polarization curves, linear polarization resistance and AC impedance spectroscopy. Different techniques have shown that generally speaking, SS316L alloys show a more corrosion resistance in artificial blood plasma in the presence of $100 \mathrm{ppm}$ amoxicillin than in the presence of $50 \mathrm{ppm}$ of amoxicillin and in the absence of amoxicillin. Their corrosion resistance is increased as the quantity of amoxicillin is increased in artificial blood plasma.
\end{abstract}

Keywords: SS316L, artificial blood plasma, amoxicillin, corrosion.

\section{Introduction}

Amoxicillin is a N-S heterocyclic compound containing five oxygen atoms, three nitrogen atoms and one sulphur atom. Hence it is expected to act as a good inhibitor. Organic inhibitors decrease the corrosion rate by adsorbing on the metal surface and blocking the active sites by displacing water molecules and form a compact barrier film on the metal surface. Amoxicillin is an antibiotic with '-electrons, hetero atoms, $\mathrm{S}, \mathrm{N}$ and $\mathrm{O}$. The molecule is high enough (molecular mass 365.4) and sufficiently planar to block more surface area (due to adsorption). These factors favour the interaction of amoxicillin with the metal [1]. SS316L alloys are the most commercially successful implantation material

\footnotetext{
*Corresponding author. E-mail address: s_johnmary@yahoo.com
} 
in biomedical. SS316L alloys are widely used as orthopedic implant materials in clinical practice; stainless steel is one of the representatives of metallic biomaterials. This is mainly due to their good corrosion resistant properties. The stainless steels typically used in medicine are austenitic stainless steels. These stainless steels contain $17-20 \% \mathrm{Cr}, 13-15 \% \mathrm{Ni}, 2-3 \%$ molybdenum and small amount of other elements. The notation "L" indicates that the steel has low carbon content $(<0.03 \%)$ and is therefore not susceptible to intergranular corrosion; due to precipitation of $\mathrm{Cr}$-carbides at the grain boundaries, stainless steel implants are used as temporary implants to help bone healing, as well as fixed implants such as artificial joints. In terms of corrosion resistance in the human body, stainless steels are inferior compared to cobalt, chromium and titanium alloys. However large amount of stainless steels are used for implant devices because they are less expensive than cobalt - chromium alloys, pure titanium and titanium alloys [2]. This study was designed to investigate the effect of SS316L in artificial blood plasma in presence of amoxicillin. People who have undergone implantation with weak immunity power are recommended by medical practitioners to take amoxicillin antibiotics to improve the immunity. By taking amoxicillin antibiotics orally increases the immunity level in our body. This study reveals whether the implantation material SS316L is affected or corroded due to the intake of amoxicillin. Different concentrations of the inhibitor (amoxicillin) were prepared and their inhibition efficiency in artificial blood plasma has been investigated.

\section{Experimental}

\section{Preparation of the specimens}

The metal specimen named SS316L has been chosen for the present study. The composition of SS 316L was (wt \%) $18 \mathrm{Cr}, 12 \mathrm{Ni}, 2.5 \mathrm{Mo},<0.03 \mathrm{C}$ and the balance iron [3]; the specimens were polished to a mirror finish, degreased with trichloroethylene, and used for weight loss study and surface examination studies. For potentiodynamic polarization studies, SS316L encapsulated in Teflon, with an exposed cross section of $5 \mathrm{~mm}$ diameter, was used as the working electrode. The working electrode surface was polished to a mirror finish and was degreased with trichloroethylene.

\section{Solution preparation}

The chemical composition of the artificial blood plasma according to PN-EN ISO 10993-15 standard ( $\mathrm{g} / \mathrm{l}$ distilled water) was $\mathrm{NaCl} 6.8, \mathrm{CaCl}_{2} 0.200, \mathrm{KCl} 0.4$, $\mathrm{MgSO}_{4}$ 0.1, $\mathrm{NaHCO}_{3} 2.2, \mathrm{Na}_{2} \mathrm{HPO}_{4}$ 0.126, $\mathrm{NaH}_{2} \mathrm{PO}_{4} 0.026$.

\section{Potentiodynamic polarization studies}

The polarization studies were carried out in a three-electrode cell assembly, using SS316L as the working electrode, platinum as the counter electrode and saturated calomel electrode (SCE) as the reference electrode. Electrochemical impedance and polarization curve measurements were achieved using $\mathrm{H} \& \mathrm{CH}$ model $\mathrm{CHI}$ 660A provided with $i \mathrm{R}$ compensation facility; polarization curve measurements 
were carried out at scan rate of $0.01 \mathrm{v} / \mathrm{sec}$. The exposed area $\left(1 \mathrm{~cm}^{2}\right)$ was mechanically polished with a series of emery sheets of variable grade. The samples were thoroughly washed with double distilled water before insertion in the cell. During the polarization study, the scan rate $(\mathrm{V} / \mathrm{s})$ was 0.01 ; hold time at Ef(s) was zero and quit time (s) was 2 . A three electrode cell assembly is shown in Scheme 1.

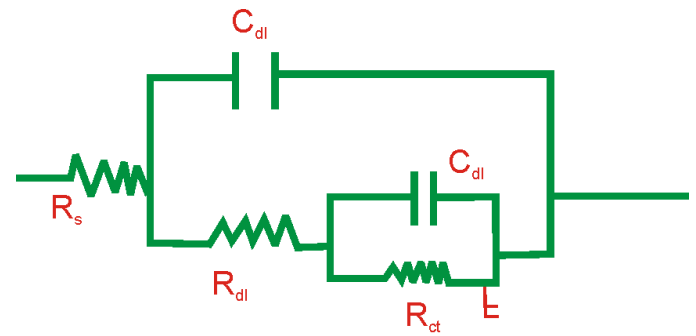

$\mathrm{R}_{\mathrm{s}}$ : Solution resistance; $\mathrm{R}_{\mathrm{dl}}$ : Double electrochemical layer resistance; $\mathrm{C}_{\mathrm{dl}}$ : Capacitance; $\mathrm{R}_{\mathrm{ct}}$ : Charge transfer resistance of the film.

Scheme 1. Equivalent circuit for two time constants.

\section{AC impedance spectra}

AC impedance spectra were recorded in the same instrument used for polarization study using the same type of three electrode cell assembly. The real part Z' and imaginary part Z" of the cell impedance were measured in Ohms for various frequencies. The charge transfer resistance $\left(\mathrm{R}_{\mathrm{t}}\right)$ and double layer capacitance $\left(\mathrm{C}_{\mathrm{dl}}\right)$ values were calculated.

$$
\mathrm{R}_{\mathrm{t}}=\left(\mathrm{R}_{\mathrm{s}}+\mathrm{R}_{\mathrm{t}}\right)-\mathrm{R}_{\mathrm{s}}
$$

where $R_{s}=$ solution resistance

$$
\mathrm{C}_{\mathrm{dl}}=1 / 2^{\prime} \mathrm{R}_{\mathrm{t}} \mathrm{f}_{\max }
$$

where $\mathrm{f}_{\max }=$ maximum frequency

$\mathrm{AC}$ impedance spectra were recorded with initial $\mathrm{E}(\mathrm{v})=0$; high frequency $(\mathrm{Hz})=$ $1 \times 10^{5}$; low frequency $(\mathrm{Hz})=10$; amplitude $(\mathrm{V})=0.005$; and quit time $(\mathrm{s})=2$.

\section{Result and discussion \\ Analysis of potentiodynamic polarization curves}

Polarization study has been used to confirm the formation of protective a film on the metal surface during the corrosion inhibition process [5]. If a protective film is formed on the metal surface, the linear polarization resistance (LPR) increases and the corrosion current value $\left(\mathrm{I}_{\text {corr }}\right)$ decreases.

The potentiodynamic polarization curves of SS 316L immersed in artificial blood plasma in the absence and presence of amoxicillin are shown in Figs. 1(a) to 1(c). Corrosion parameters, namely corrosion potential, $\mathrm{E}_{\mathrm{corr}}, \mathrm{I}_{\mathrm{corr}}$, Tafel slopes, $\mathrm{b}_{\mathrm{a}}, \mathrm{b}_{\mathrm{c}}$, and LPR are given in the Table 1.

When the SS 316L is immersed in artificial blood plasma in absence of amoxicillin the corrosion potential is $-410 \mathrm{mV}$ vs. SCE (Fig.1(a)). The LPR value is $0.825 \times 10^{6} \mathrm{Ohm} \mathrm{cm}^{2}$ and the corrosion current $\left(\mathrm{I}_{\text {corr }}\right)$ is $6.097 \times 10^{-8} \mathrm{~A} / \mathrm{cm}^{2}$. The Tafel slopes $\left(b_{c}=154 \mathrm{mV} /\right.$ decade, $b_{a}=460 \mathrm{mV} /$ decade $)$ indicate that the 
rate of change of corrosion current with potential is much higher during the anodic polarization than during the cathodic polarization. During anodic polarization an oxide film is formed on the metal surface in presence of SS 316L.

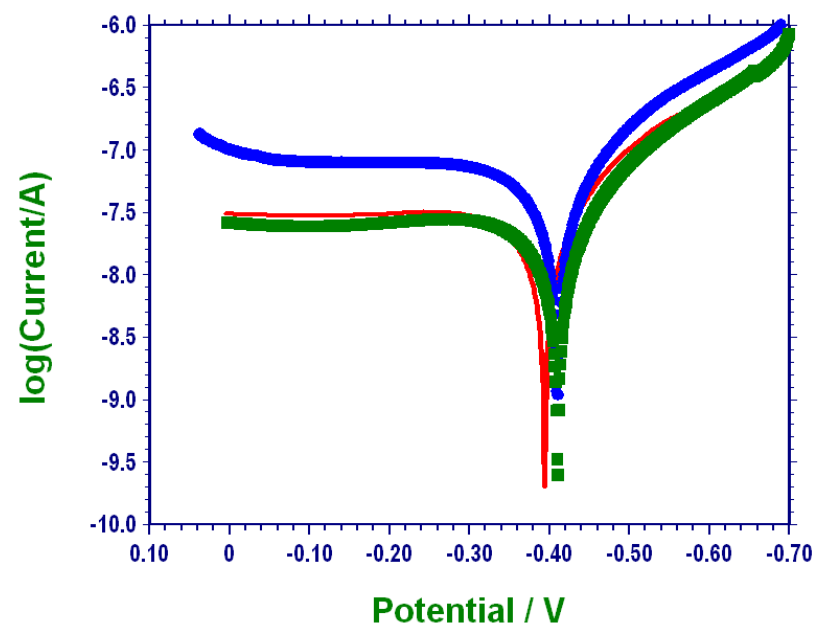

Figure 1. Polarization curves of SS 316L alloys immersed in various test solutions : (a) artificial blood plasma (blank), b) SS 316L + ABP + $50 \mathrm{ppm}$ of amoxicillin and (c) SS $316 \mathrm{~L}+\mathrm{ABP}+100 \mathrm{ppm}$ of amoxicillin.

Table 1. Corrosion parameters of SS $316 \mathrm{~L}$ alloys immersed in artificial blood plasma (ABP) in the absence and presence of $50 \mathrm{ppm}$ and $100 \mathrm{ppm}$ amoxicillin, obtained from polarization study.

\begin{tabular}{|c|c|c|c|c|c|c|}
\hline Metal & System & $\begin{array}{c}\mathbf{E}_{\text {corr }} \\
\text { mV vs. SCE }\end{array}$ & $\begin{array}{c}\mathbf{b}_{\mathrm{c}} \\
\mathrm{mV} / \text { decade }\end{array}$ & $\begin{array}{c}\mathbf{b}_{\mathrm{a}} \\
\mathrm{mV} / \text { decade }\end{array}$ & $\begin{array}{c}\text { LPR } \\
\mathrm{Ohm} / \mathrm{cm}^{2}\end{array}$ & $\mathbf{I}_{\text {corr }} \quad \mathbf{A} / \mathrm{cm}^{2}$ \\
\hline \multirow{3}{*}{ SS316L } & ABP & -410 & 154 & 460 & $0.825 \times 10^{6}$ & $6.097 \times 10^{-8}$ \\
\hline & $\begin{array}{l}\mathrm{ABP}+ \\
\text { Amoxicillin } 50 \mathrm{ppm}\end{array}$ & -394 & 153 & 583 & $1.64 \times 10^{6}$ & $3.216 \times 10^{-8}$ \\
\hline & $\begin{array}{l}\text { ABP + } \\
\text { Amoxicillin } \\
\text { ppm }\end{array}$ & -411 & 148 & 576 & $1.86 \times 10^{6}$ & $2.740 \times 10^{-8}$ \\
\hline
\end{tabular}

The polarization study reveals that the corrosion resistance of SS 316L in artificial blood plasma increases in presence of $50 \mathrm{ppm}$ of amoxicillin. When SS $316 \mathrm{~L}$ is immersed in ABP in presence of $50 \mathrm{ppm}$ of amoxicillin the corrosion potential is shifted from -410 to $-394 \mathrm{mV}$ vs. SCE Fig.1(b). The Tafel slopes $\left(b_{c}=153 \mathrm{mV} /\right.$ decade, $b_{a}=583 \mathrm{mV} /$ decade) indicate that the rate of change of corrosion current with potential is much higher during anodic polarization than during the cathodic polarization. It shows that in presence of amoxicillin it acts as better corrosion resistance than in absence of amoxicillin. Further the LPR value increases from $0.825 \times 10^{6} \mathrm{Ohm} \mathrm{cm}^{2}$ to $1.64 \times 10^{6} \mathrm{Ohm} \mathrm{cm}^{2}$. The corrosion current $\left(\mathrm{I}_{\text {corr }}\right)$ decreases from $6.097 \times 10^{-8} \mathrm{~A} / \mathrm{cm}^{2}$ to $3.216 \times 10^{-8} \mathrm{~A} / \mathrm{cm}^{2}$. Thus the polarization study confirms the formation of a protective film on the metal surface.

When $100 \mathrm{ppm}$ of amoxicillin are added, the corrosion potential is increased from -410 (in absence of amoxicillin) and decreased from -394 (in presence of 50 
ppm of amoxicillin) to $-411 \mathrm{mV}$ vs. SCE Fig.1(c). LPR value increases from $0.825 \times 10^{6}$ (in absence of amoxicillin) and $1.64 \times 10^{6}$ (in presence of $50 \mathrm{ppm}$ of amoxicillin) to $1.86 \times 10^{6} \mathrm{Ohm} \mathrm{cm}^{2}$ and $\mathrm{I}_{\text {corr }}$ value decreases from $6.097 \times 10^{-8}$ (in absence of amoxicillin) and $3.216 \times 10^{-8}$ (in presence of $50 \mathrm{ppm}$ of amoxicillin) to $2.740 \times 10^{-8} \mathrm{Ohm} \mathrm{cm}^{2}$. Thus the polarization study leads to the corrosion resistance of SS $316 \mathrm{~L}$ in $\mathrm{ABP}$ in the following decreasing order:

SS $316 \mathrm{~L}+\mathrm{ABP}+100 \mathrm{ppm}$ of amoxicillin $>\mathrm{SS} 316 \mathrm{~L}+\mathrm{ABP}+50 \mathrm{ppm}$ of amoxicillin $>\mathrm{SS} 316 \mathrm{~L}+\mathrm{ABP}$

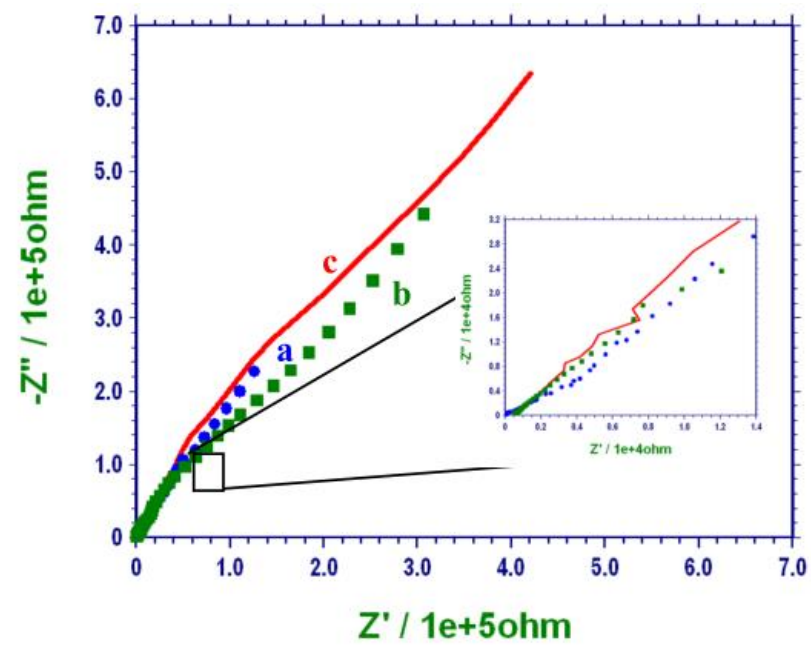

Figure 2. AC impedance spectra of SS 316L immersed in various test solutions (Nyquist plot): (a) artificial blood plasma (blank), (b) SS 316L + ABP + 50 ppm of amoxicillin, (c) SS 316L + ABP + 100 ppm of amoxicillin.

\section{AC impedance spectra}

AC impedance spectra have been used to confirm the formation of a protective film on the metal surface [6]. If a protective film is formed on the metal surface, charge transfer resistance $\left(R_{t}\right)$ increases, double layer capacitance value $\left(C_{d l}\right)$ decreases and the impedance log $(\mathrm{z} / \mathrm{Ohm})$ value increases $[7,8]$.

The AC impedance spectra of metal specimens immersed in artificial blood plasma in the absence and presence of $50 \mathrm{ppm}$ and $100 \mathrm{ppm}$ of amoxicillin are shown in Fig.2 (a,b,c) (Nyquist plots) and Fig.3 (a,b,c) (Bode plots).

The AC impedance parameters namely charge transfer resistance $\left(\mathrm{R}_{t}\right)$ and double layer capacitance $\left(\mathrm{C}_{\mathrm{dl}}\right)$ derived from Nyquist plots are given in Table 2. The impedance $\log (\mathrm{z} / \mathrm{Ohm})$ values derived from Bode plots are given also in Table 2.

\section{SS 316L immersed in artificial blood plasma in absence and in presence of amoxicillin}

When SS 316L is immersed in ABP in absence of amoxicillin, the charge transfer resistance $R_{t}$ is $1292000 \mathrm{Ohm}^{2}$. The double layer capacitance value is $3.94 \times 10^{-11} \mathrm{~F} / \mathrm{cm}^{2}$ (Fig.2(a)). The impedance value is 5.4 (Fig.3(a)). Bode phase diagram on Fig.3(a) shows two time constants; a highly capacitive, typical of passive materials, suggests that the film formed on the alloy is more stable. The 
phase angle approaches $67^{\circ}$. The equivalent circuit is shown in scheme $1[9,10]$. It is inferred that SS 316L is more corrosion resistant in ABP. The oxide layer formed on SS 316L is more compact and less fragile $[9,10]$.
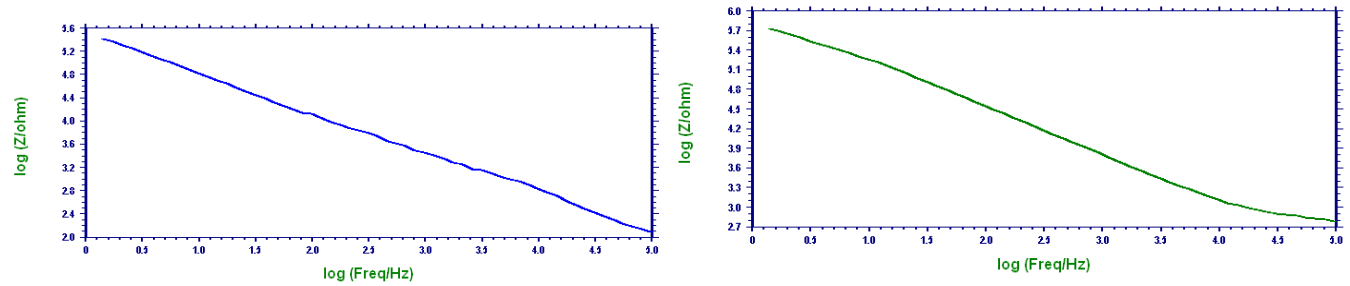

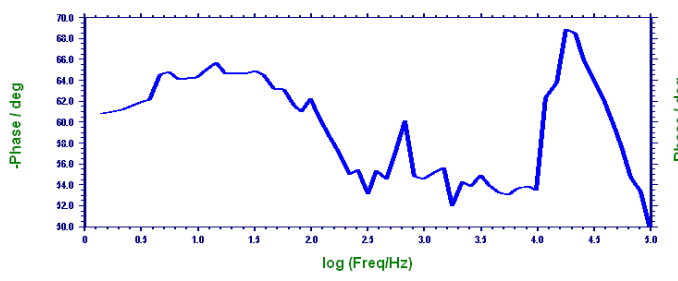

(a)

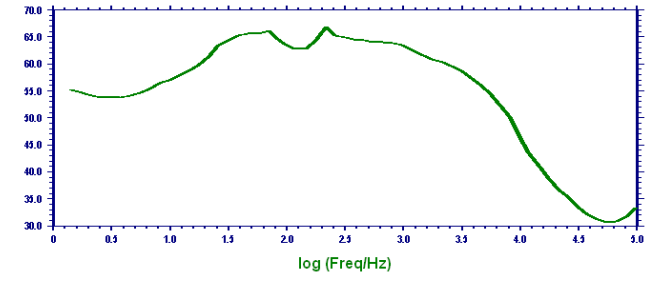

(b)
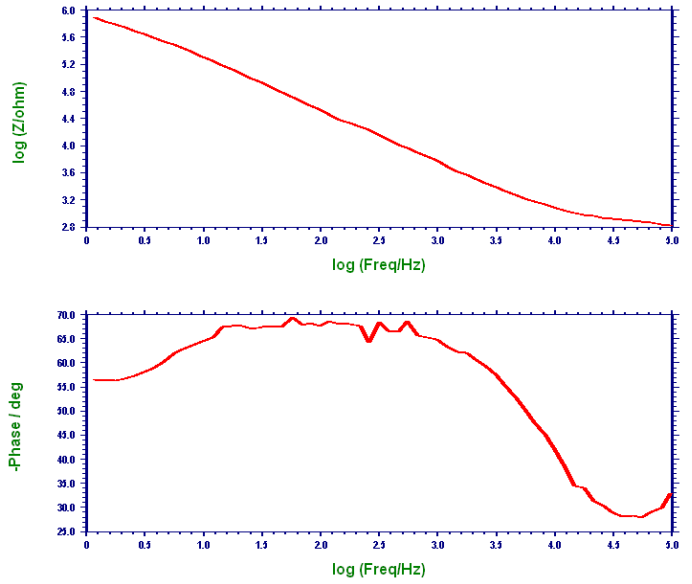

(c)

Figure 3. Bode plots of SS 316L immersed in various test solutions containing: (a) artificial blood plasma (blank), (b) SS 316L + ABP + 50 ppm of amoxicillin, and (c) SS 316L + ABP + 100 ppm of amoxicillin.

Table 2. Corrosion parameters of SS 316L alloy immersed in artificial blood plasma (ABP) in the absence and presence of $50 \mathrm{ppm}$ and $100 \mathrm{ppm}$ of amoxicillin obtained from AC impedance spectra.

\begin{tabular}{|c|c|c|c|c|}
\hline \multirow[b]{2}{*}{ Metal } & \multirow[b]{2}{*}{ System } & \multicolumn{2}{|c|}{ Nyquist plot } & Bode plot \\
\hline & & $\begin{array}{c}R_{t} \\
\text { Ohm cm } \text { cm }^{2}\end{array}$ & $\mathrm{C}_{\mathrm{dl}} \mathrm{cm}^{2} \mathrm{~F} /$ & $\begin{array}{r}\text { Impedance } \\
\log (\mathrm{z} / \mathrm{Ohm})\end{array}$ \\
\hline \multirow{3}{*}{$\begin{array}{l}\text { SS } \\
316 \mathrm{~L}\end{array}$} & $\mathrm{ABP}$ & 129200 & $3.94 \times 10^{-11}$ & 5.4 \\
\hline & $\mathrm{ABP}+50 \mathrm{ppm}$ Glu & 309200 & $1.64 \times 10^{-11}$ & 5.7 \\
\hline & $\mathrm{ABP}+100 \mathrm{ppm} \mathrm{Glu}$ & 423800 & $1.2 \times 10^{-11}$ & 5.8 \\
\hline
\end{tabular}

When SS 316L is immersed in ABP containing $50 \mathrm{ppm}$ amoxicillin, the charge transfer resistance $\mathrm{R}_{\mathrm{t}}$ increases from $129200 \mathrm{Ohm} \mathrm{cm}^{2}$ to $309200 \mathrm{Ohm} \mathrm{cm}^{2}$ Fig.2(b). The $C_{\mathrm{dl}}$ value decreases from $3.94 \times 10^{-11} \mathrm{~F} / \mathrm{cm}^{-2}$ to $1.64 \times 10^{-11} \mathrm{~F} / \mathrm{cm}^{-2}$. Bode phase diagram shown in Fig.3(b) shows that the diameter of the semicircle 
is increased so the corrosion resistance is increased. Corrosion rate is decreased. This is further supported by the phase angle, which is $68^{\circ}$. The impedance value $\log (\mathrm{z} / \mathrm{Ohm})$ increases from 5.4 to 5.7 [11-13].

When 100 ppm amoxicillin is added the $R_{t}$ value increases from 129200 (in absence of amoxicillin) and 309200 (in presence of $50 \mathrm{ppm}$ of Amoxicillin) to $423800 \mathrm{Ohm} \mathrm{cm}{ }^{2}$ Fig.2(c). The $\mathrm{C}_{\mathrm{dl}}$ value decreases from $3.94 \times 10^{-11}$ (in absence of amoxicillin) and $1.64 \times 10^{-11}$ (in presence of $50 \mathrm{ppm}$ of amoxicillin) to $1.2 \mathrm{x}$ $10^{-11} \mathrm{~F} / \mathrm{cm}^{2}$. The impedance value increases from 5.4 (in absence of amoxicillin) and $5.7 \log (\mathrm{z} / \mathrm{Ohm})$ (in presence of $50 \mathrm{ppm}$ of amoxicillin) to $5.8 \log (\mathrm{z} / \mathrm{Ohm})$. Through the impedance Bode plot one can see that as the value of the frequency increases the impedance value decreases sharply being the slope of the straight line almost 0.5 . This is a characteristic of a stable film formed on the surface of a metal during corrosion protection process. This is further supported by the phase angle of Bode plot. The value of the phase angle is $69^{\circ}$. Thus $\mathrm{AC}$ impedance spectral study reveals that the corrosion resistance of SS $316 \mathrm{~L}$ in ABP is in the following decreasing order:

SS 316L + ABP + 100 ppm Amoxicillin > SS 316L + 50 ppm Amoxicillin > SS 316L+ $\mathrm{ABP}$

\section{Acknowledgement}

The authors are thankful to their respective management and to UGC for their encouragement and to Mr. S. Elango for his computer aided design.

\section{References}

1. Harikumar S, Karthikeyan S, Narayanan S. Amoxicillin drug on the corrosion of mild steel in $1 \mathrm{~N}$ hydrochloric acid solution. Int $\mathrm{J}$ Chem Tech Res. 2012;4:1077-1084.

2. Talha Mohd, Behera CK, Sinha P. Potentiodynamic polarization stud of type $316 \mathrm{~L}$ and $316 \mathrm{LVM}$ stainless steels for surgical implants in simulated body fluids. J Chem Pharm Res. 2012;4:203-208.

3. Gurapp I. Characterization of different materials for corrosion resistance under simulated body fluid conditions. Mater Characterization. 2002;49:7379.

4. Kajzer W, Krauze A, Walke W, Marciniak J. Corrosion Behaviour of AISI 316L steel in artificial body fluids. J Achiev Mater Manuf Eng. 2008;31.

5. Nazeer AA, Fouda AS, Ashno EA. Inhibition effect of cysteine towards the corrosion of $\mathrm{Cu} 10 \mathrm{Ni}$ alloy in sulfide polluted saltwater electro chemical and impedance study", J Mater Environ Sci. 2011;2:24-38.

6. ThangamYY, Kalanithi M, Anbarasi CM, Rajendran S. Inhibition of corrosion of carbon steel in a dam water by sodium molybdate- $\mathrm{Zn}^{2+}$ system. Arab J Sci Eng. 2009;34.

7. Abdullah M. Antibacterial drugs as corrosion inhibitors for corrosion of aluminium in $\mathrm{HCl}$ solutions. Corrosion Sci. 2004;466:1981-1996. 
8. Rajendran S, Uma V, Krishnaveni A, Jeyasundari J, Shyamaladevi B, Manivannan M. Corrosion behaviour of metals in artificial saliva in presence of D-Glucose", Arab J Sci Eng. 2009;34.

9. Castaneda IE, Gonzalez-Rodriguez JG, Dominguez G, Sandoval-Jabalero R, Ecriflores MA, Chacon-Nava JG, Fane AM-V. Corrosion behaviour of $\mathrm{Ni}-\mathrm{Al}-\mathrm{Cu}$ alloys in simulated human body solution. Int $\mathrm{J}$ Electrochem Sci. 2011;6:404-418.

10. Application note on Basics of Electrochemical impedance spectroscopy by Gamry Instruments.

11. Antony N, Sherine HB, Rajendran S. Arab J Sci Eng. 2010;35:41.

12. Rajendran S, Devi KM, Regis APP, Raj AJA, Jeyasundari J. Zastita Materijala. 2009;50:153.

13. Raji A, Rajendran S, Prabha PS, Selvi JA, Narayanasamy B, Jeyasundari J. Zastita Materijala. 2009;50:131. 